\title{
The Analysis of Pedagogic Competency Culinary Teacher of Implementation Curriculum 2013
}

\author{
I Ketut Suartana ${ }^{1,}{ }^{*}$, Ni Kadek Indah Kumari Dely ${ }^{2}$ \\ ${ }^{1}$ Study Program of Pendidikan Kesejahteraan Keluarga. University of Dhyana Pura Bali, Indonesia \\ ${ }^{2}$ Study Program of Pendidikan Kesejahteraan Keluarga. University of Dhyana Pura Bali, Indonesia
}

\section{Abstract}

The purpose of this study was (1) to describe the pedagogical competence of teachers in the majoring in culinary on the implementation of Curriculum 2013; (2) to describe the obstacles culinary experienced teachers in the implementation of Curriculum 2013. This study used a qualitative research with case studies (qualitative case study) to obtain in-depth information regarding the implementation of Curriculum 2013. The study was conducted in seven vocational schools in the Badung regency who implements 2013. The school curriculum is used in this research was determined by purposive sampling with the base CMS implements the curriculum of 2013. The subjects were all teachers Hospitality in vocational teaching in classes X, XI, and XII are used as a place of research. Meanwhile the object of this study is the pedagogical competence of teachers in curriculum implementation 2013. Data collection techniques used in this study includes observational techniques non participants, documentation, and semi-structured interview. Observation techniques are used to seeing the implementation of learning majoring in food service in class X, IX and XII to implement ccurriculum 2013 interview techniques used to obtain information readiness, obstacles to teachers in implementing appropriate learning in the majoring in culinary Curriculum 2013. The conclusions of this study were: 1) pedagogical competence of teachers catering services in Badung are in accordance with the demands of the curriculum, 2013. In connection with the activities Teacher Performance Assessment there are 7 (seven) aspects and 46 (forty six) indicators developed in respect of mastery pedagogical competence according to Regulation No. 74 of 2008. From the findings, it seemed that all the indicators have been achieved with the criteria very well. With excellent ability pedagogical competence will allow teachers to implement the curriculum in 2013, especially in the culinary learning.
\end{abstract}

Keywords:

Pedagogical competence, Curriculum 2013,

Culinary

\section{Introduction}

The one of innovation that doing by government to increase the quality of Indonesia education is Curriculum Implementation 2013. Curriculum 2013 is the action of sustainable from curriculum before is Curriculum based on Competency and Curriculum of Unit Level Education (Kurikulum Tingkat Satuan Pendidikan). The completion of curriculum is the action of the purpose national education. The change of Curriculum is carried out as an action to solve various problems of moral nation quality, the quality of human resources and the challenge of development science and technology. Curriculum 2013 concerns with attitude domain (spiritual, social), knowledge and skill domain. The four aspects next is will become basic for making the Core of Competency and eleborate to Basic Competence. Curriculum 2013, the guide of study and the book teaching have settled from center government. However teacher must be consistent to create the study process oriented with attitude, knowledge and skill aspects.

By the guidance of developing curriculum 2013 is said that the study in vocational high school is hoped to create the students productive, active and affective through attitude strengthen, skill, and integration of knowledge. Competence in curriculum previously lowered of a subjects now turned into subjects derived from competence. Approach (part of the learning) is more directed on the subjects of compulsory, optional and vocational.

\footnotetext{
* Corresponding author.

E-mail Address: suartana.undhira@gmail.com (I Ketut Suartana)
} 
Culinary is one of the majors that is in vocational high school, learning culinary in substance is activity undertaken consciously by learners that produces a change manner on itself in the form of knowledge, skill and attitude with regarding to culinary. The knowledge of culinary covering knowledge of the menu, in the kitchen, cake recipe, primary of food stuff, food stuffs additional, bumcurribu cook, cooking technique, preparing and packaging food.

Teacher's culinary as educator major culinary in accordance with a record and tasks teachers according to Indonesia Republic Act no.14, 2005 was educator professional in education culinary who have the main task as educator, learner, supervisor, steering, coach, assessor and evaluator. Competence to be owned teachers in accordance with government regulation no. 19, 2005 including teachers culinary that is pedagogical competency, personality competency, professional competency and social competency. Pedagogical competency that is the ability to manage learning students covering of understanding of school tuition, design and implementation learning, evaluation study results and development school tuition to actualize various its potential. Personality Competency is the ability of established personality, stabilize, mature, wise and influential, be a role model for learners and have a moral. Professional competency is learning their ability of the material culinary in a broad and deep that allows guiding school tuition meet the standard of competence which was set in national education standards. Culinary teachers as a professional need to have expertise, skillfulness and skill in culinary who fulfill quality standard. Social competency is the ability of educator as part of the community to communicate and they blend effectively with school tuition, fellow educator, of teaching staff parents or guardian learners and the community.

In implementing learning in curriculum 2013, required ability related to the content (content) or way to studying matter. This approach is known as PCK's approach (pedagogical content knowledge). Shulman (1986) in S.K Abell, D.L. Hanuscin, M. H. Lee, M J Gagnon (2008) give the think that to tea ch it is not enough to understand content matter but also teaching (how to teach). Teacher must have knowledge to the learner, curriculum, instructional strategy, assessment so that can do transformation science knowledge. The emerged of curriculum 2013 need adjustment in the leaning based on curriculum 2013. This is also become a reference LPTK in preparing teacher candidates culinary to have competence in accordance with set out in curriculum 2013. The preparation of teachers' program culinary at the level of the LPTK need data analysis needs of the field. These needs analysis covering the ability pedagogy, the ability content matter required in the implementation of the curriculum 2013 and constraints teachers culinary in implementing learning in curriculum 2013. Based on the background above, it is relevant to do research analysis pedagogic competence teachers culinary in implementing learning according to curriculum 2013. The purpose to be achieved in this research is as follows: 1) to describe the competence pedagogical teachers in their experiences culinary on the implementation of the curriculum 2013,2) to describe teacher barriers culinary happened to the curriculum for the implementation of 2013.

\section{Method}

This research used the qualitative study to the study cases (qualitative case study) to obtain more information on the implementation of curriculum 2013. This research has done in seven vocational high schools in the Badung regency which is implemented curriculum 2013. Schools that used in this research is determined through purposive sampling on the basic of the method of vocational high school who are at the city center. The subject of study it is a whole of teachers culinary in vocational high school who follow in the classroom X, XI, and XII as the place for research. Where as the objects of this research was pedagogical teachers competency in implementing curriculum 2013.

Technique data collection used in this research include observation non participants technique, documentation, and semi-structured the interview. Technique observation used to look the implementation of learning culinary in the class X, IX and XII who apply curriculum 2013. Interview techniques used to get information readiness, teacher obstacles in carrying out learning culinary curriculum 2013. Qualitative data obtained of observation technique, the interview and documentation of next analyzed qualitative using a technique analysis by Miles and Huberman (1994: 12), consisting of measures as follows.

\section{The Data Classification}

Questionnaire Data is given classified by grouping answer of the respondents who being equal. Questionnaire Data, the answer every grains about scored on each alternative answers. Alternative answers always scored 3, rarely scored 2, never scored 1 . The results of data the questionnaire analyzed 
by adding up a score answer then counted in the form of the percentage (Ali, 1993) through formula as follows:

Score competence pedagogical teachers culinary $=(\mathrm{n} / \mathrm{N}) \times 100 \%$

Note: $\mathrm{n}=$ the number of the score that obtained

\section{Display Data}

After the classification of the data, so the next step is to display. Sugiyono (2010) said in qualitative study, the presentation of data can be done in an overview, chart, and the relation between category, flowchart, and others. This research using presentation of data with the text which is narrative. Data presented in this research shaped in descriptive summary and systematic of the results obtained, so that central theme can be seen easily; and summary given any explanation with regarding to appropriateness with the focus of research. The expected of data obtained will be easier to understand what happened, the data can be organized and there were relation pattern and could plan next work based on what has been understood.

\section{Conclusion}

The last step is the verification data or make conclusion. Conclusion in qualitative research answering the formulation problems that formulated since early, but may have not, because problems and formulation problems in qualitative research still temporary and develop the study in the field. The activities at this stage are: (1) test results that taken by comparing theory that suggested experts, especially the undirected relevant; (2) to do checking repeated from for granting the questionnaire, interview, and documentation; (3) make conclusion to be reported as a result of research. The conclusion that obtainable to expect is the focus of research formulated and in the form of new finding

\section{Result and Discussion}

\section{Result Of Research}

The research was conducted in vocational high school (SMK) using curriculum 2013 to get data pedagogic competence teachers culinary in implementing the curriculum 2013. By 16 existing vocational high school in Badung regency, there are 7 vocational high schools for using the curriculum 2013. The results of questionnaire respondents from their respective vocational high schools implement curriculum 2013 of culinary program completely can be seen in the Table 02 .

Table 02. The results of questionnaire teacher's culinary which is implements curriculum 2013

\begin{tabular}{|c|c|c|c|c|c|c|c|c|}
\hline \multirow{2}{*}{ NO } & \multirow{2}{*}{ DESCRPTION } & \multicolumn{7}{|c|}{ TEACHER PEDAGOGICAL COMPETENCY (\%) } \\
\hline & & A1 & A2 & A3 & A4 & A5 & A6 & A7 \\
\hline A & Controlling the characteristic of learner & & & & & & & \\
\hline 1 & $\begin{array}{l}\text { Identification the study characteristic every } \\
\text { students in the class. }\end{array}$ & 91,7 & 96,7 & 100 & 95,2 & 93,3 & 94,4 & 100 \\
\hline 2 & $\begin{array}{l}\text { Ensuring that all students get the same } \\
\text { opportunity to participate actively involved } \\
\text { in learning activities. }\end{array}$ & 100 & 100 & 100 & 100 & 100 & 100 & 100 \\
\hline 3 & $\begin{array}{l}\text { Managing the classes to give learning } \\
\text { opportunities the same in all participants } \\
\text { students with a disorder physical and ability } \\
\text { to learn different. }\end{array}$ & 75,0 & 96,7 & 100 & 85,7 & 93,3 & 100 & 100 \\
\hline 4 & $\begin{array}{l}\text { Trying to determine the cause of } \\
\text { irregularities behavior students to prevent } \\
\text { the activities to other students. }\end{array}$ & 100 & 100 & 85,7 & 100 & 100 & 83,3 & 100 \\
\hline 5 & $\begin{array}{l}\text { Helping to develop the potential and } \\
\text { overcoming deficiency learners. }\end{array}$ & 100 & 100 & 100 & 100 & 93,3 & 100 & 100 \\
\hline 6 & $\begin{array}{l}\text { Observing learners by weakness certain } \\
\text { physical activity to follow learning. }\end{array}$ & 66,7 & 100 & 95,2 & 100 & 93,3 & 100 & 100 \\
\hline B & $\begin{array}{l}\text { Controlling theoretical learning and } \\
\text { principle learning educate }\end{array}$ & & & & & & & \\
\hline
\end{tabular}




\begin{tabular}{|c|c|c|c|c|c|c|c|c|}
\hline \multirow{2}{*}{ NO } & \multirow{2}{*}{ DESCRPTION } & \multicolumn{7}{|c|}{ TEACHER PEDAGOGICAL COMPETENCY (\%) } \\
\hline & & $\mathrm{A} 1$ & $\mathrm{~A} 2$ & A3 & A4 & A5 & A6 & A7 \\
\hline \multirow[t]{2}{*}{7} & Giving chances to students to over matter & & & & & & & \\
\hline & $\begin{array}{l}\text { learning appropriate age and the study by } \\
\text { setting learning and activity varying. }\end{array}$ & 83,3 & 95,8 & 95,2 & 90,5 & 93,3 & 100 & 100 \\
\hline 8 & $\begin{array}{l}\text { Ensuring their level of understanding } \\
\text { students material certain to learning and } \\
\text { adjust activity on the learning next this } \\
\text { understanding. }\end{array}$ & 100 & 100 & 95,2 & 90,5 & 80,0 & 100 & 100 \\
\hline 9 & $\begin{array}{l}\text { Explaining the reason the implementation of } \\
\text { the activities and activity that they did, good } \\
\text { appropriate and different to a plan, } \\
\text { regarding their learning, }\end{array}$ & 100 & 95,8 & 100 & 90,5 & 100 & 100 & 100 \\
\hline 10 & $\begin{array}{l}\text { Using various techniques to motivate his } \\
\text { willingness to learn students. }\end{array}$ & 100 & 100 & 95,2 & 100 & 93,3 & 100 & 93,3 \\
\hline 11 & $\begin{array}{l}\text { Planning learning activities that mutually } \\
\text { related to another, with regarding to the } \\
\text { purpose of learning and learning process } \\
\text { learners. }\end{array}$ & 100 & 100 & 95,2 & 95,2 & 100 & 94,4 & 100 \\
\hline 12 & $\begin{array}{l}\text { Considering the students / not fully } \\
\text { understand learning material taught and } \\
\text { uses it to correct learning next design. }\end{array}$ & 10 & 95,8 & 100 & 100 & 100 & 100 & 100 \\
\hline $\mathrm{C}$ & Developing Curriculum & & & & & & & \\
\hline \multirow{2}{*}{$\begin{array}{l}13 \\
14\end{array}$} & Composing syllabus according to curriculum. & 75,0 & 100 & 95,2 & 100 & 93,3 & 100 & 100 \\
\hline & $\begin{array}{l}\text { Designing education planning according to } \\
\text { syllabus to discuss matter of teaching } \\
\text { students certain in order to reach } \\
\text { competence has been set. }\end{array}$ & 100 & 95,8 & 95,2 & 100 & 100 & 100 & 100 \\
\hline 15 & $\begin{array}{l}\text { Following in order subject learning with } \\
\text { regarding to the purpose of learning. }\end{array}$ & 100 & 91,6 & 90,5 & 100 & 100 & 100 & 100 \\
\hline 16 & $\begin{array}{l}\text { Choosing the material learning that in } \\
\text { accordance with the purpose of learning. }\end{array}$ & 83,3 & 95,8 & 100 & 100 & 100 & 100 & 100 \\
\hline $\mathrm{D}$ & Learning activities of educating & & & & & & & \\
\hline 17 & $\begin{array}{l}\text { Implementing the activity of learning } \\
\text { according to a draft developed a complete } \\
\text { and the implementation of the activity show } \\
\text { that teachers understand the purpose. }\end{array}$ & 100 & 100 & 100 & 100 & 100 & 100 & 100 \\
\hline 18 & $\begin{array}{l}\text { Implementing the activity of learning aimed } \\
\text { at helping learning students. }\end{array}$ & 100 & 100 & 95,2 & 100 & 100 & 94,4 & 100 \\
\hline 19 & $\begin{array}{l}\text { Communicating new information (for } \\
\text { example additional subject) accordance with } \\
\text { the age of and the ability to learn students. }\end{array}$ & 75,0 & 87,5 & 81,0 & 85,7 & 93,3 & 100 & 100 \\
\hline \multirow{2}{*}{$\begin{array}{l}20 \\
21\end{array}$} & Facing the mistake as the students learning. & 100 & 95,8 & 90,5 & 100 & 100 & 88,9 & 100 \\
\hline & $\begin{array}{l}\text { Conducting the learning activities based on } \\
\text { the curriculum and related with contexts of } \\
\text { life learner. }\end{array}$ & 100 & 91,7 & 100 & 100 & 93,3 & 100 & 100 \\
\hline 22 & $\begin{array}{l}\text { Doing the various activities learning with } \\
\text { fairly time to learning activities that } \\
\text { appropriate with age and the study ability } \\
\text { degree and keep looking the learner. }\end{array}$ & 100 & 100 & 95,2 & 95,2 & 93,3 & 94,4 & 100 \\
\hline 23 & $\begin{array}{l}\text { Managing the classroom and effective } \\
\text { without dominate or preoccupied with his } \\
\text { own that all the time participants used } \\
\text { productively. }\end{array}$ & 100 & 95,8 & 100 & 100 & 100 & 100 & 100 \\
\hline 24 & $\begin{array}{l}\text { Able to operate audio visual (include TIK) to } \\
\text { increase the learner motivation learning for } \\
\text { reaching the purpose study. Matching the } \\
\text { activity learning that designed with class } \\
\text { condition. }\end{array}$ & 91,7 & 75,0 & 81,0 & 95,2 & 100 & 100 & 93,3 \\
\hline 25 & $\begin{array}{l}\text { Giving many opportunities for students to } \\
\text { ask. }\end{array}$ & 100 & 100 & 95,2 & 100 & 100 & 100 & 100 \\
\hline 26 & $\begin{array}{l}\text { Setting the implementation of the activity of } \\
\text { learning systematically to help learning } \\
\text { students. For example: teachers add new } \\
\text { information after evaluating understanding }\end{array}$ & 100 & 91,6 & 100 & 100 & 93,3 & 100 & 100 \\
\hline
\end{tabular}




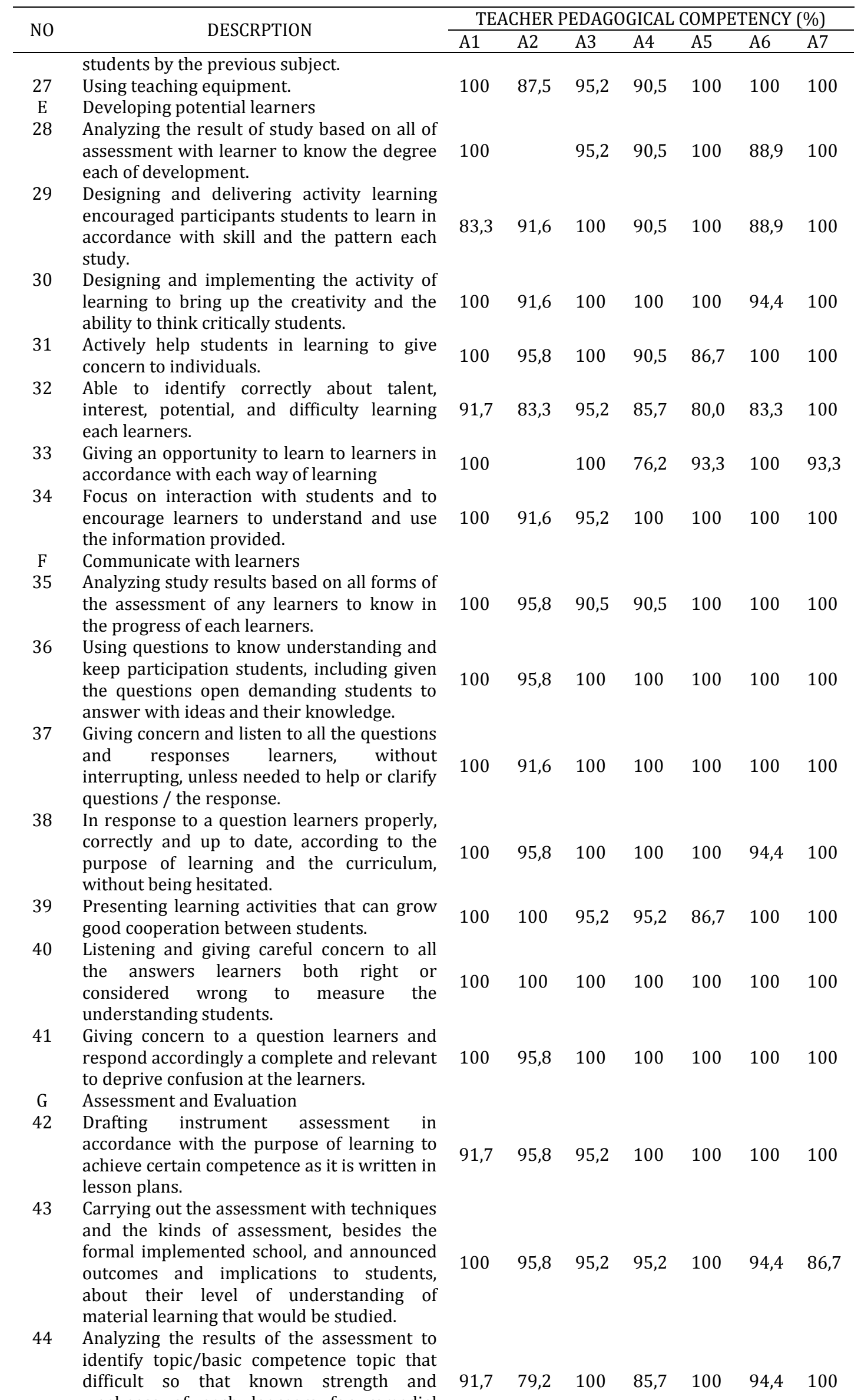
weakness of each learners for remedial purposes and enrichment. 


\begin{tabular}{|c|c|c|c|c|c|c|c|c|}
\hline \multirow{2}{*}{ NO } & \multirow{2}{*}{ DESCRPTION } & \multicolumn{7}{|c|}{ TEACHER PEDAGOGICAL COMPETENCY (\%) } \\
\hline & & $\mathrm{A} 1$ & $\mathrm{~A} 2$ & A3 & $\mathrm{A} 4$ & A5 & A6 & A7 \\
\hline 45 & $\begin{array}{l}\text { Using input from learners and reflected to } \\
\text { promote next learning, and could prove it } \\
\text { through note, the journal learning, the } \\
\text { learning, additional subject, and so on. }\end{array}$ & 100 & 79,2 & 95,2 & 95,2 & 80,0 & 100 & 100 \\
\hline 46 & $\begin{array}{l}\text { Taking the assessment as a draft learning to } \\
\text { do next. }\end{array}$ & 100 & 79,2 & 100 & 100 & 86,7 & 94,4 & 100 \\
\hline
\end{tabular}

Note:

A1 : SMK Pariwisata Mengwitani

A2 : SMK Nusa Dua

A3 : SMK PGRI Badung

A4 : SMK Prshanti Nilayam

A5 : SMK Pariwisata Triatmajaya

A6 : SMK Wira Harapan

A7 : SMK Widya Mandala

\section{Disscussion}

The first things pedagogic competence to owned by teachers are figure out the characteristics of learners. Teachers have to understand the principles the development of personality school tuition in order to actualize various potential possessed by learners. Teachers culinary in Badung regency is considered already understand the characteristic learners, this can be seen on the results of research. Understanding characteristic learners important because relating to the development of students includes physical aspects, moral, spiritual, culturally emotional, and intellectual. Teachers have to understanding will be the characteristics, the learners and development, understand a few the concept of education useful to help learners, control in a method of teaching according to the subject matter and development of students, the evaluation systems proper and good. Knowing characteristic of students, teachers can find a solution when problems occur in learning.In addition, by understanding characteristic every students, teachers can determine appropriate approach applied to students.

The second pedagogic competence to be controlled by teachers are control theoretical learning and the learning of the principle, the curriculum 2013 demanded to concern learning not only lessons. Components are healthy not only the cognitive but also affective and phsycomotoric. Kemendikbud (2013) said the curriculum 2013 emphasis on dimensions pedagogic modern in learning, that is using scientific approach. To optimize learning to improve liveliness students, teachers need to control various theoretical learning, approach, method, model and learning that educate strategy. The curriculum 2013 stressed the approach scientific or scientific approach, that teachers apply this approach to the utmost and knowledge of this approach also got known teachers.

The third pertaining of competence pedagogical is to develop curriculum can be seen from the capability of teachers to determine the purpose of learning and choose material in accordance with the approach and the character of learners. The ability of teachers develop a curriculum very good support in changing curriculum 2013 demanding curriculum teachers to can construct learning that the process of indicating deftness of learners. Requiring teachers meet core competence which contains nation character. Teachers who originally made the syllabus and lesson plans in accordance with the condition of each school now be required to draw up lesson plans which corresponds to the syllabus from government and should also see from the condition of the school where teaching. So that all the demands can be met then the ability of teachers develop the curriculum must be high.

The fourth is ability pedagogic was able to perform learning activities of discipline. Teachers have drafted as respondents planning complete learning that includes cognitive aspects, affective, and psychomotoric. It was also established learning that educate in classrooms, laboratory, and the field. They are holding in accordance with the demand in curriculum 2013. Usman H and Nuryadin ER (2013) said learning is not only for exploration, elaboration, and confirmation but also to raise student competency in conducting observations (listen, see, read, hear), asked, association, conclusion, communicating either verbally, written, and also body language.

The curriculum 2013 emphasized that subject teachers have to integrate lessons TIK in any learning. An analysis of the results showed to the five about utilize information and telecommunication technology can be said has been met with very good. The teacher had use information technology and communication in learning it using laptops, lcd projector, and use wifi facilities.To achieve this question is very in accordance with the demand curriculum 2013. To integrate TIK lessons, teachers as educator must surely knowing the information technology and communication. Teachers who has mastered 
communication and information technology can get the learning to students in large numbers and dispersed anywhere. Teachers not only control students studying in class, but also be able to individual service at the same time.

The fifth of pertaining pedagogic competence to the development of potential students. The result showed teachers meet competence of indicators pedagogic facilitate the development of potential learners by providing learning activities but in classrooms. Usman Hand Nuryadin ER (2013) said learning is exploration, elaboration, and confirmation to transform, preserve, and critize science and technology and the culture done inside and outside the classroom. Providing learning business outside the classroom could help students more creative in doing learning. Learners can see directly the phenomenon happened in the environment. Real experiences obtained students will help in the tency advancement themselves.

The sixth pedagogic competence is communication skills. Communication skills teachers culinary in Badung regency with students are simply met good enough. The ability to communicate very important and support in learning. Competence at least a teacher new is teaching of the skills in the opening and closing lessons, asking, giving strengthening, and making variation of teaching. If a teacher has the ability to class, so students would be easy to catch material that was delivered.

The seventh pedagogic competence concerned with the assessment and evaluation. Kemendikbud (2013) said the curriculum 2013 has done by mixing three aspects knowledge, skills, and attitude. Requiring teachers to assessing and evaluating processes and results either from the test cognitive, affective and psychomotor. Fulfilling the indicators pedagogic competency is very important. The curriculum 2013 stressed based learning problem. The learning with PBL done with authentic asssesment (Kemendikbud 2013). The portfolio PBL can use in assessment learning. Teachers doing the test to know developing students and arranging in accordance with the rules of every school. With the arranging assessment and portfolio assessment and the development of students in learning can be seen. The administration this assessment will be used to determine completed study students especially for culinary program.

\section{Conclusions}

The conclusions of the research is: 1) pedagogic competence teachers culinary in Badung regency have in accordance with the demand curriculum 2013. Pertaining to a teacher assessment activities are 7 (seven) aspects and 46 (forty six) indicator developed regarding ability pedagogic competence according to the government regulation no 74 in the year 2008. The research showed that all indicators had been reached on very good. The pedagogic competence become very good will facilitate teachers in implementing curriculum 2013 especially in learning culinary. The advice of the research is: 1) the government especially the district education office Badung need to socialize 2013 curriculum evenly on each school and done soon to prevent the curriculum in 2013,2) The school and related government needs to give training or educate teachers culinary that do not have licence of culinary and the ability of pedagogic teachers can be improved.

\section{References}

Firmansyah F. 2007. Implementasi Kurikulum Tingkat Satuan Pendidikan (Struktur dan Kendalanya). Tadris 2 (1):134-144.

Kemendikbud. 2013. Materi Pelatihan Guru Implementasi Kurikulum 2013 SMP/MTs Ilmu Pengetahuan Alam.

Jakarta: Kementerian Pendidikan dan Kebudayaan.

Miles, Matthew B \& Huberman, A. Michael. 1994. Analisis Data Kualitatif. (Terjemahan Tjetjep Rohendi Rohidi). Jakarta: Universitas Indonesia Press.

Peraturan Menteri Pendidikan dan Kebudayaan Republik Indonesia Nomor 54 Tahun 2013 tentang Standar Kompetensi Lulusan Pendidikan Dasar dan Menengah. 2013. Jakarta: Menteri Pendidikan dan Kebudayaan Republik Indonesia.

Peraturan Menteri Pendidikan dan Kebudayaan Republik Indonesia Nomor 54 Tahun 2013 tentang Standar Isi Pendidikan Dasar dan Menengah. 2013. Jakarta : Menteri Pendidikan dan Kebudayaan Republik Indonesia

Peraturan Menteri Pendidikan dan Kebudayaan Republik Indonesia Nomor 68 Tahun 2013 tentang Standar Kompetensi Lulusan Pendidikan Dasar dan Menengah. 2013. Jakarta : Menteri Pendidikan dan Kebudayaan Republik Indonesia 
Peraturan Menteri Pendidikan dan Kebudayaan. 2013. Peraturan Menteri Pendidikan dan Kebudayaan nomor 69 tahun 2013 tentang Kerangka Dasar dan Struktur Kurikulum Sekolah Menengah Atas/Madrasah Aliyah. Jakarta : Kementerian Pendidikan dan Kebudayaan.

Sugiyono. 2011. Metode Penelitian Kuantitatif Kualitatif dan R\&D. Bandung : Alfabeta.

Undang-Undang Sistem Pendidikan Nasional No 20 Tahun 2003.

Usman H \& Nuryadin ER. Strategi Kepemimpinan Pembelajaran Menyongsong Implementasi Kurikulum 2013. Cakrawala Pendidikan 32 (1):1-13 